\title{
Anxiolytic Effect Evaluation of Methanol Extract of Ceplukan Leaves in the Elevated Plus Maze Test through IL-6 Level Changes in Ovariectomized Rat
}

\author{
Siti Nurfitria ${ }^{1}$, Nur Permatasari $i^{*}$, Retty Ratnawati ${ }^{3}$
}

\author{
${ }^{1}$ Master Program of Biomedical Sciences, Faculty of Medicine, University of Brawijaya, Malang, East Java, Indonesia \\ ${ }^{2}$ Pharmacology Department, Faculty of Medicine, University of Brawijaya, Malang, East Java, Indonesia \\ ${ }^{3}$ Physiology Department, Faculty of Medicine, University of Brawijaya, Malang, East Java, Indonesia
}

\section{ABSTRACT \\ Ceplukan (Physalis minima L.) has long been used to treat various conditions in traditional medicine.} This study aims to demonstrate the anxiolytic effects of Methanol Extract of Ceplukan Leaves (MECL) in the Ele vated Plus Maze (EPM) test and correlate to IL-6 level of ovariectomized rat brain. Total of 24 Wistar rats were divided into six groups: one normal group, one group of 1 month ovariectomized (ovx), one group of 2 months ovx, three groups of 2 months ovx (each given with MECL 500; 1500 and $2500 \mathrm{mg} / \mathrm{kg}$ doses for 1 month). The anxiety-like behavior level was measured by EPM test. After EPM test, the brain was removed to measure level of IL-6 by ELISA. The data were processed and analyzed by one-way ANOVA and Pearson correlation. We found that the MECL-treated rats enter the opened-arm higher than the control rats. It indicates that the MECL-treated rats are less anxious than the control rats. The results also show the decreased of IL-6 level in MECL-treated rats.

Keywords: anxiety-like behavior, elevated plus maze, IL-6, Physalis minima L.

\section{INTRODUCTION}

Anxiety is a major symptom in menopausal women which showed by the high rates of anxiety in menopausal women $[1,2]$. Previous research shows the relationship between anxiety with increase of proinflammatory cytokine IL-6 [3-5]. At menopause, the production of IL-6 may increased which triggered by the state of estrogen deficiency [6,7]. Estrogen replacement therapy usually used to treat menopausal symptoms. However, HRT raises new problems such as increasing risk of breast cancer, endometrial cancer, venous thromboembolic disease, stroke and ovarian cancer [8]. To avoid such problems, the researchers begin to study the effectiveness of phytoestrogens from natural plants which has estrogen-like effects.

Ceplukan plant (Physalis minima L.) has long been used for traditional treatment in Indonesia for various diseases, such as purgative, antihelmintic, febrifuge, and vermifuge. Steroidal lactones from ceplukan believed to have antifertility effect, hypoglycemic, cytotoxic, antiulcer, anti-bacterial, anti-malarial and anti-

\footnotetext{
${ }^{*}$ Corresponding author:

Nur Permatasari

Faculty of Medicine, University of Brawijaya

Malang, Indonesia

E-mail: nungky.permatasari@gmail.com
}

gonorrhea [9]. Mulchandani et al. (1979) showed that the plant contained of fisalin steroid $A$, fisalin $B$, fisalin $\mathrm{C}$, fisalin $\mathrm{D}$, wita fisalin $\mathrm{A}$, wita fisalin $\mathrm{C}$ and 5.6 epoxy fisalin [10]. There were similarities between mechanism of Physalis minima L. extract and $17 \beta$-estradiol, so Physalis minima L. can be classified as phytoestrogens [11]. Even so there was no further research whether ceplukan could reduce anxiety in menopausal women.

The aim of the study was to determine whether MECL has anxiolytic effect on EPM test through the changes of IL-6 level in the rat brain after ovariectomy.

\section{MATERIALS AND METHODS \\ Animals}

Three-month female Wistar rats (Rattus norvegicus) (195 $\pm 3 \mathrm{~g}$; $\mathrm{n}=24)$, weighing before and after experiment, kept in cages made of a plastic with a lid made of woven wire cage, with a cycle of 12 hours light/dark, fed and watered by ad libitum. After 7 days acclimatization, the experimental animals were divided into 6 groups (each consist of 4 rats): one normal group, one group of 1 month ovx, one group of 2 month ovx, 3 groups of 2 months ovx (each treated with MECL 500; 1500 and $2500 \mathrm{mg} / \mathrm{kg}$ doses for 1 month). All procedure were approved by Health Research Ethics Com- 


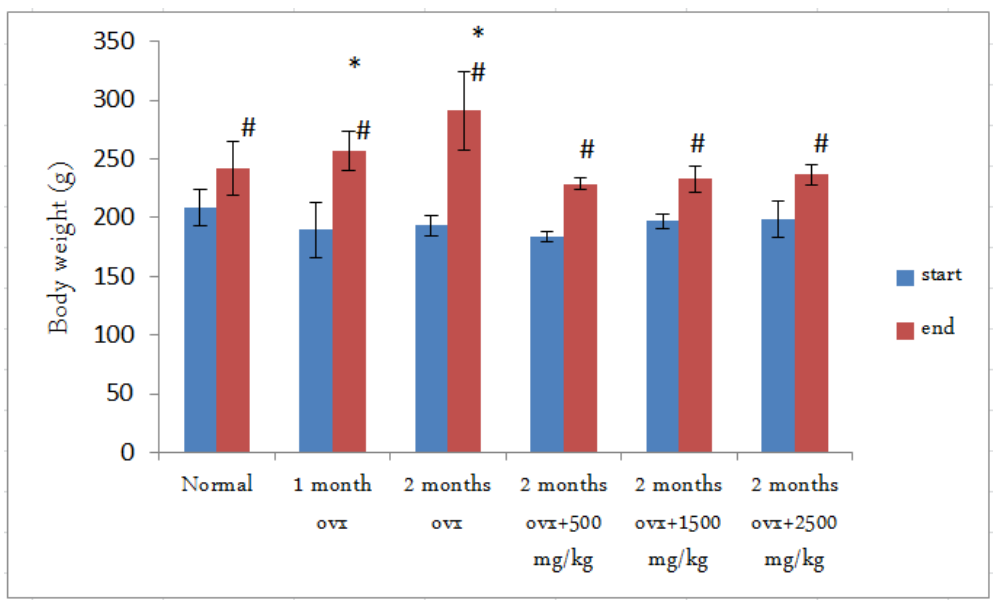

Figure 1. Body weight changes in normal and ovx rats with and without MECL treatment. Body weight was measured from the start to the end of experiment; \# $\mathrm{p}<0,05$ compared with other group by oneway ANOVA analysis; ${ }^{*} \mathrm{p}<0,05$ compared with other group at Tukey Post Hoc analysis. The data were expressed as means \pm SD.

mittee of University of Brawijaya.

\section{Sample Preparation}

Ceplukan leaves were obtained from Balai Tanaman Obat Materia Medika, Batu, Indonesia. Ceplukan leaves (dry powder) that have been weighed and wrapped in filter paper, inserted in funnel extraction then soaked with methanol to obtain the compounds. The solution from immersion process then collected and precipitated. The solution was separated and collected from the precipitated product then dried in rotator evaporator at $70-80^{\circ} \mathrm{C}$ to obtain the thick extract. The product then heated in oven at $70^{\circ} \mathrm{C}$ to remove the remaining methanol.

\section{Ovariectomy}

The rats were anaesthetized by intramuscular (IM) injection of ketamine $(40 \mathrm{mg} / \mathrm{kg})$. Hair at ventral was

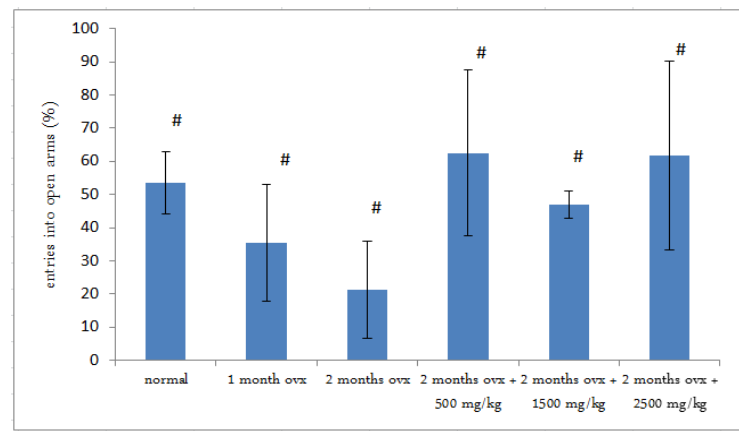

A shaved approximately $1 \mathrm{~cm}$ above the imaginary line ovaries. The site then cleaned with povidone-iodine and alcohol $70 \%$. The paralumbar lateral incision was made using a sharp knife and the ovaries were removed. The wound was sutured using catgut and covered by sterile gauze. Each rat was injected with gentamicin $(60-80 \mathrm{mg} / \mathrm{kg}, \mathrm{IM})$ and cleaned with povidoneiodine during 3 days after surgery to prevent postoperative infection.

\section{Behavior Test}

Behavioral assessment using EPM test, a standard test to measure anxiety-like behavior in rats $[12,13]$. The EPM apparatus was made of wood which has two open arms $(50 \times 10 \mathrm{~cm})$, two contradictory close arms (50x10x40 cm) with an open square in the middle $(10 \times 10 \mathrm{~cm})$, placed $50 \mathrm{~cm}$ above the floor. The open arms then given a $1 \mathrm{~cm}$ wall. The arms basis was put

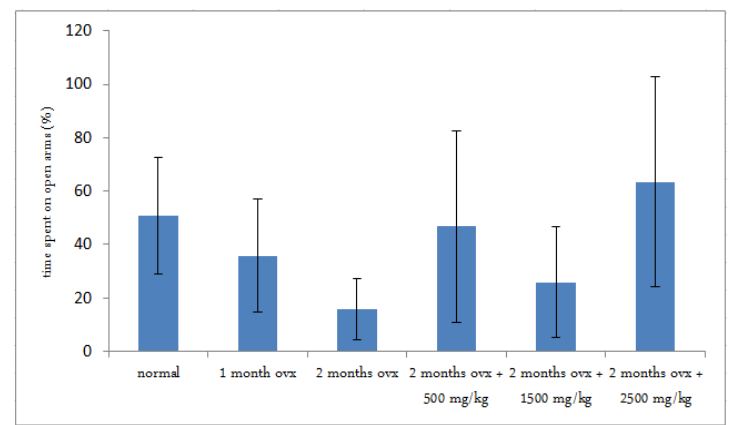

B

Figure 2. A. Open arm entry, B. Open arm time as determined by EPM test in normal and ovx rats with and without MECL treatment; $\# \mathrm{p}<0,05$ compared with other group by oneway ANOVA analysis; ${ }^{*} \mathrm{p}<0,05$ compared with other groups at Tukey Post Hoc analysis. The data were expressed as means \pm SD. 


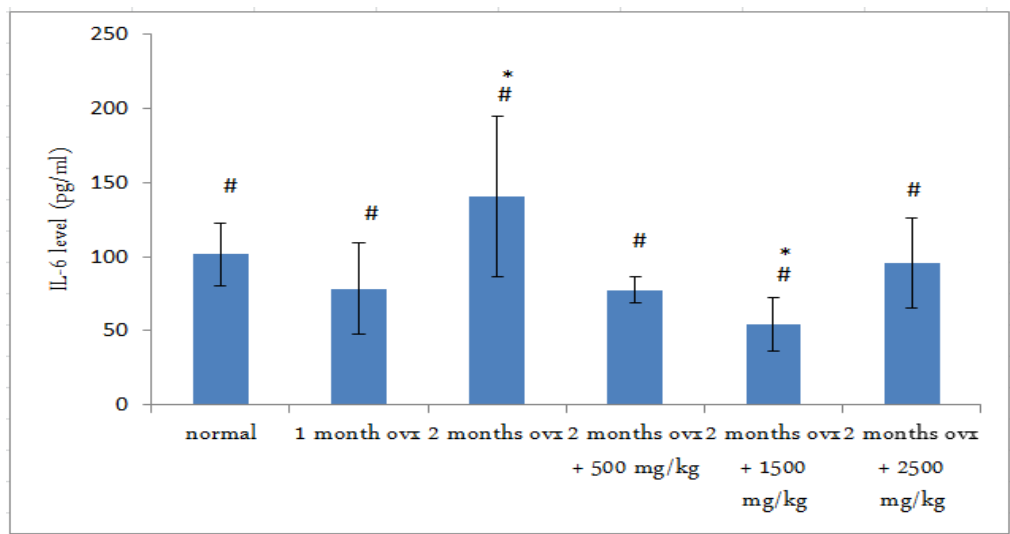

Figure 3. Level of IL-6 brain rats in normal and ovx rats with and without MECL treatment; \#p $<0,05$ compared with other groups by oneway ANOVA analysis; * $\mathrm{p}<0,05$ compared each other at Tukey Post Hoc analysis. The data were expressed as means $\pm \mathrm{SD}$.

up rough plastic to facilitate the cleansing of rats feces [13-15]. The instrument placed at closed room which had low noise and low lighting. Tests carried out for each rat at the same hour every day (at 16:00 pm to 18:00 pm). During the EPM test, the rats were placed in the apparatus and let it explored the maze for 5 minutes. The rat activities were recorded by using video. The video then analyzed for: a) percentage of rat entered the open arms (total for each rat) b) percentage of total time spent in the open arms [16]. Rat which entered the arms was defined as all four paws being placed in the arms.

\section{Measurement of IL-6 level}

After the EPM test, the rats were exposured to ether vapor and their brains were removed after cardiac perfussion. The hippocampus were dissected out on an ice-bath plate B, based on [17], the hippocampus was taken off approximately $100 \mathrm{mg}$ and washed with distilled water and $1 \mathrm{ml}$ PBS. The protein of the tissue was extracted by homogenizing the tissue in lysis buffer PMSF (containing Tris base 0,1211 g; EDTA 0,0074 g; $\mathrm{NaCl}$ 0,8775 g; 0,009 g PMSF; NP 40 0,125 ml, 100 $\mathrm{ml}$ diionized, protease inhibitor cocktail $50 \mu \mathrm{L}$ ) about 2 minutes. The mixture was then incubated 30 minutes at $40^{\circ} \mathrm{C}$ and cold centrifuged at $6000 \mathrm{rpm}$ for $10 \mathrm{~min}-$ utes. The supernatant was taken to measure IL-6 levels using Quantikine Rat IL-6 kit (R \& D Systems, USA \& Canada) according to the manufacture instructions.

\section{Statistical Analysis}

The results were expressed as means \pm SD. Multiple comparisons were analyzed by one-way analysis of variance (ANOVA) followed by post-hoc analysis with Tukey method. The relationship between two variables were examined using Pearson correlation method. The level of significance was $\mathrm{p}<0,05$. All statistical tests were performed by SPSS 17.00 .

\section{RESULTS AND DISCUSSION \\ Body Weight}

Ovariectomy significantly increased the body weight. Rats which given 1 month ovx and 2 months ovx respectively gained the body weight; 67 grams and 97,5 grams. Significantly different with normal rats which only gained 33 grams. The results of oneway ANOVA analysis shows that there are significant differences on body weight gain $(\mathrm{p}=0.000)$ in all groups. Further analysis using Tukey's Post Hoc Test shows that there are significant differences on weight gain between 1 month ovx and 2 months ovx groups with the other groups $(\mathrm{p}<0,05)$ (Fig. 1$)$.

\section{Behavior Test}

The EPM results show that anxiety-like behavior in ovx rats is increased. Treated rats for 1 month and 2 months ovx have lower percentage of open-arm entries and open-arm time than others. The MECL-treated rats has a greater number of percentage total rat entered the open arms $(p<0,05)$. Groups of Ovx + MECL more often entered the open arms, so they have greater percentage (respectively 62,5\%, 46,95\% and 61,67\%) compared to 2 months ovx rats which only $21,4 \%$. The results indicate an anxiolytic-like effect of MECL in rats. Dose of $500 \mathrm{mg} / \mathrm{kg}$ give the lowest levels of anxiety (Fig.2A).

The EPM results show that MECL-treated rats spent more time in the open arms, however the results of oneway ANOVA shows no significant differences between the six-groups of rats $(p=0,190)$ (Fig.2B).

\section{IL-6 Levels}


As shown in Fig.3, the level of IL-6 on 2 months ovx group is higher than normal group $(140,63 \mathrm{pg} / \mathrm{ml}$ compared to $101,65 \mathrm{pg} / \mathrm{ml})$. Interestingly, the level of IL-6 on 1 month ovx group is lower than normal rats. All three dosage MECL used in this study (500, 1500 and $2500 \mathrm{mg} / \mathrm{kg} /$ day) significantly decreased IL-6 level in the hippocampus of ovx rats $(\mathrm{p}<0,05)$. Further analysis using Tukey's Post Hoc Test shows that there are significant differences between groups of rats which given MECL $1500 \mathrm{mg} / \mathrm{kg}$ with 2 months ovx rats $(\mathrm{p}<0,05)$.

To determine the relationship between the anxiolytic effects of MECL with the levels of IL-6 in treated rats, we used Pearson correlation analysis. The results show no significant relationship between the percentage of the rat entered the open arms and level of IL-6 $(\mathrm{p}>0,05)$, with a weak correlation coefficient $(\mathrm{r}=0,008)$. Furthermore, Pearson correlation analysis was also use to determine the relationship between the percentage of rats spending time in the open arms and level of IL6 . The result show no significant correlation between the percentage of rat spending time in the open arms and level of IL-6 ( $>>0,05)$, with a weak correlation coefficient $(r=0,019)$.

The present study showed that the body weight in the 1 month and 2 months ovx rats increased significantly compared to the group without ovariectomy, it indicates that ovariectomy on this study is successful [18]. The results also show that anxiety-like behavior in each rat groups have a high standard deviation. The standard deviation shows the distribution of the average individual, in other words the higher value gives higher variation [19]. The high variations of anxietylike behavior is caused by the parameters related to "trait", where animal has a wide range which reflected high variation in the dimensions of the human personality $[13,20]$.

The increasing of anxiety-like behavior in ovx rats without MECL showed on EPM test, although only a percentage of total rat entering the open arms which gave statistically significant result $(\mathrm{p}<0,05)$. While the result of total spending time percentage in the open arms showed not significance. Previous study showed indices of anxiety can vary independently [16]. This study not in accordance with previous study, which analysis factor of time spent in the open arms should contribute more to anxiety than the rat enter the open arms $(-0,95$ compared to $-0,86)$ using EPM test [21]. The cause is most likely due to the manual apparatus in this study. This is consistent with previous references which show different laboratories will produce varying EPM data test [22].

The MECL showed an anxiolytic effect. The effect is confirmed by all three dosage used in this study (500, 1500 and $2500 \mathrm{mg} / \mathrm{kg} / \mathrm{day})$ which reduced anxiety-like behaviour in EPM test. Dose of $2500 \mathrm{mg} / \mathrm{kg}$ showed consistency on reducing anxiety, both at percentage of total rat entered the open arms and percentage of total time spent in the open arms. There is no specific pattern of dose-response curve.

The result showed that the levels of IL- 6 on brain in 2 months ovx rats is the highest within groups. Interestingly, the level of IL- 6 in the brain of 1 month ovx rats group is lower than normal group. This is probably caused by the differences between natural menopause with surgical menopause related with acute changes in estrogen levels. Gradual changes in natural menopause causes the recovery of immune function through feedback mechanisms, but surgical menopause will alter immune function so that the cytokine levels could be lower than the normal value [23].

The present study demonstrate that MECL can reduce the levels of IL-6 in the brain. Level of IL-6 in the MECL-treated rats are lower than those of 2 months ovx rats. These results are consistent with previous studies in which level of IL-6 in 24 months ovx, decreased after treated by isoflavone that classified as phytoestrogens [24]. The ability of MECL to reduce level of IL-6 in the brain, indirectly prove estrogen-like effect of ceplukan leaves. The mechanism may through the estrogen receptor (ERs). Estrogens or phytoestrogens will show biological activity after binding to ERs. Activated ERs will block NFkB gene by changing the conformation of protein and unable to activate the IL-6 gene promoter. Activated ER by estrogen will give biological effects on NF-kB with protein conformational changes which lead to the inability to bind DNA [7].

Statistical analysis shows that there is no significant relationship between the anxiolytic effects of MECL with IL-6 level in brain of MECL-treated rats. The results show that the decreasing of anxiety-like behavior in MECL-treated rats is not through decreasing levels of IL-6, but through other pathway. The accepted path is serotonergic pathway. Estrogen affects the serotonin system by increasing the degradation of monoamine oxidase, an enzyme that breaks down serotonin, and affecting serotonin transport intraneuron, which result in increasing the availability of serotonin in the synapse, and changing the mood into good feeling [25].

Previous studies examining the potential of diosgenin, one of phytoestrogens, as an anxiolytic agent 
leads to reversed U-shaped dose-response curve [26]. No previous studies which examined the anxiolytic effects of MECL. This study did not obtain a specific pattern of dose-response curves. It probably caused by a few amount of treatment doses. So further research is recommended to increase the treatment doses.

\section{CONCLUSIONS}

The methanol extract of ceplukan leaves (Physalis minima L.) shows anxiolytic effects by using EPM test. It does not through changes on the level of IL-6 in ovariectomized rat brain. Further research is suggested to investigate molecular mechanism of the anxiolytic effects.

\section{ACKNOWLEDGMENT}

This work was supported by grants from BOPTNThe Operational Funding Assistance for State Universities, University of Brawijaya, Indonesia (DIPA023.04.2-414-989/2013).

\section{REFERENCES}

1. Zhou B, Sun X, Zhang M, Deng Y, Hu J (2011) The symptomatology of climacteric syndrome: whether associated with the physical factors or psychological disorder in perimenopausal/postmenopausal patients with anxietydepression disorder. Arch Gynecol Obstet. 285: 13451352.

2. Aprilia NI, Puspitasari N (2007) Faktor yang Mempengaruhi Tingkat Kecemasan pada Wanita Perimenopause. The Indonesian Journal of Public Health. 4(1): 35-42.

3. Ai AL, Seymour EM, Kronfol Z, Bolling SF (2011) Mood states, coping factors, and interleukin-6 are related to psychiatric symptoms following cardiac surgery. Biological Psychiatry And Psychopharmacology. 13: (1).

4. O’Donovan A, Hughes BM, Slavich GM, Lynch L, Cronin MT, O'Farrelly C, Malone KM (2010) Clinical anxiety, cortisol and interleukin-6: Evidence for specificity in emotion-biology relationships. Brain, Behavior, and Immunity. 24: 1074-1077.

5. Morozink JA, Friedman EM, Coe CL, Ryff CD (2010) Socioeconomic and Psychosocial Predictors of Interleukin6 in the MIDUS National Sample. Health Psychol. 29(6): 626-635.

6. Rachon D, Mys'liwska J, Suchecka-Rachon'K, Wie ،ckiewicz J, Mys'liwski A (2002) Effects of oestrogen deprivation on interleukin- 6 production by peripheral blood mononuclear cells of postmenopausal women. Journal of Endocrinology.172: 387-395.

7. Pfeilschifter J, Ko“Ditz R, Pfohl M, Schatz H (2002) Changes in Proinflammatory Cytokine Activity after
Menopause. Endocrine Reviews. 23(1): 90-119.

8. Goodman NF, Cobin RH, Ginzburg SB, Katz IA, Woode DE (2011) American association of clinical endocrinologist guidelines for medical clinical practices for the diagnosis and treatment of menopause. Endocrine Practice. 17.

9. Chotani D, Vaghasiya HU (2012) A phyto-pharmalogical overview of Physalis minima Linn. Indian Journal of natural products and resources. 3(4): 477-482.

10. Tarannita C, Permatasari N, Sudiarto (2006) Efek Hambatan Ekstrak Daun Ceplukan (Physalis Minima L.) Terhadap Kontraktilitas Otot Polos Usus Halus Terpisah Marmut dengan Stimulasi Metakolin Eksogen. Jurnal Kedokteran Brawijaya. 22(1): 18-23.

11. Permatasari N, Nurdiana, Karyono S (2010) Efek non genomik dan genomik ekstrak daun ceplukan (Physalis minima L.) pada kultur sel endotel manusia (HUVECs). Jurnal Ilmu Hayati. 22: 14-19

12. Belzung C, Griebel G (2001) Measuring normal and pathological anxiety-like behavior in mice: a review. Behavioural Brain Research.125: 141-149.

13. Pawlak CR, Karrenbauer BD, Schneider P, Ho YJ (2012) The elevated plus maze test: Differential psychopharmacology of anxiety-related behaviour. Emotion Review. 4(1): 98-115.

14. Charoenphandhu J, Teerapornpuntakit J, Nuntapornsak, Amporn K, Nateetip and Charoenphandhu N (2011) Anxiety-like behaviors and expression of SERT and TPH in the dorsal raphé of estrogen- and fluoxetine-treated ovariectomized rats Pharmacology. Biochemistry and Behavior. 98: 503-510.

15. Ho YJ, Wang CF, Hsu WY, Tseng T, Hsu CC, Kao MD, Tsai YF (2007) Psychoimmunological effects of dioscorea in ovariectomized rats: role of anxiety level. Annals of General Psychiatry. 6(21).

16. Lister RG (1987) The use of a plus-maze to measure anxiety in the mouse. Psychopharmacology. 92: 180-185.

17. Kjonigsen LJ, Leergaard TB, Witter MP, Bjaalie JG (2011) Digital atlas of anatomical subdivisions and boundaries of the rat hippocampal region. Frontiers in Neuroinformatics. 5: 1.

18. Rogers NH, Perfield II JW, Strissel KJ, Obin MS, Greenberg AS (2009) Reduced Energy Expenditure and Increased Inflammation Are Early Events in the Development of Ovariectomy-Induced Obesity. Endocrinology. 150: 2161-2168.

19. Barde MP, Barde PJ (2012) What to use to express the variability of data: Standard Deviation or Standard Deviation of Means?. Perspectives in Clinical Research. 3.

20. Steimer T (2002) The biology of fear- and anxiety-related behaviours. Dialogues Clin Neurosci. 4: 231-249

21. Rodgers RJ, Dalvi (1997) Anxiety, Defence and the Ele- 
vated Plus-maze. Neurscience and Biobehavioral Reviews. 21(6): 801-810.

22. Wahlsten D, Metten P, Philips TJ, Boehm II SL, Burkhart-Kasch S, Dorow J et al. (2003) Different Data from Different Labs: Lessons from Studies of Gene-Environment Interaction. J Neurobiol. 54(1): 283-311.

23. Tani A, Yasui T, Matsui S, Kato T, Tsuchiya N, Yuzurihara M, Kase Y, Irahara M (2014) Circulating level of monocyte chemoattractant protein-1 and interleukin-7 in women who have undergone bilateral salpingo-oophorectomy. Journal of Inflammation Research. 7: 1-7.

24. Kireev RA, Tresguerres ACF, Gracia C, Borras (2010)
Hormonal regulation of pro-inflammatory and lipid peroxidation processes in liver of old ovariectomized female rats. Biogerontology. 11: 229-243.

25. Douma SL, Husband C, O'Donnell ME, Barwin BN, Woodend AK (2005) Estrogen-related Mood Disorders Reproductive Life Cycle Factors. Advances in Nursing Science. 8(4): 364-375.

26. Ho YJ, Tai SY, Pawlak CR, Wang AL, Cheng CW, Hsich MH (2012) Behavioral and IL-2 Responses to Diosgenin in Ovariectomized Rats. Chinese Journal of Physiology. 55(2): 91-100. 